\title{
Newspapers on education policy: constructing an authoritative public voice on education \\ Sue Thomas
}

\author{
School of Education and Professional Studies (Brisbane, Logan), \\ Faculty of Education, Griffith University, Australia. \\ s.thomas@griffith.edu.au
}

In 2006, one Australian newspaper, The Australian, published a series of items on education. The Australian, published by Rupert Murdoch’s News Ltd, is the biggest-selling national newspaper in Australia. Established in the sixties as a left-liberal newspaper, it has increasingly moved to the right. More recently, Murdoch has used The Australian to push economic liberalism onto the political agenda of many governments (Hobbs, 2007). Indeed, Hobbs (2007) notes that The Australian "abandoned all pretence to critical, balanced journalism during 2003, and, instead, use the editorial and opinion pages of its Australian titles to further arguments calling for Australia’s involvement in the 2003 invasion of Iraq” (p. 266). Similar campaigns have been conducted on industrial relations (2007) (cf.Buchanan, 2008) and on education (2002-2008) (cf. Freesmith, 2006; McLeod \& Yates, 2006; Snyder, 2008), as senior members in the then Federal Government and their supporters in the Murdoch press created public controversies designed to propagate their ideology and to defend their policies (Buchanan, 2008). Indeed in late 2007, “The Australian was informally known among some in the media and policy circles at the time as ' the Government Gazette’” (Buchanan, 2008, p. 34).

The series of items published in The Australian in 2006 was part of one such campaign that worked to construct an authoritative public voice on education that questioned the quality of Australian schooling and teachers. Teacher quality was an important element of the then Federal Government’s education policy as evidenced by the Australian Government Quality 
Teacher Programme (AGQTP). This chapter analyses the ways in which the newspaper constructed a particular version of what good teachers should be within the policy context of the Australian Quality Teacher Programme. That is, it explores the interrelationships between the public debates on teacher quality in the media and the policies on teacher quality that formed the basis of the AGQTP. The chapter then examines the contribution of senior members of the federal government to these debates. In so doing, the chapter shows how critical discourse analysis can provide a framework for understanding, and exploring, the interface between government, media and education policy.

The chapter first outlines a framework that conceptualises media and policy texts as public discourses, that is, of discourses in the public sphere, and of the public sphere as discursive space. It argues that such a conceptualisation enables investigations into the interface, or conjunctures, between discourses in the public sphere. Critical Discourse Analysis (CDA) is identified as a suitable means for analysing these discourses (Thomas, 2006). Next, the chapter traces the discourses on quality constructed in both the education policies of the AQTP and in items about education in The Australian. The analysis shows how policy and media texts in public debates on quality in Australia constructed three discourses on teacher quality and standards. They were discourses of quality assurance, of quality improvement and of common sense (Sachs, 2003). The analysis traces the construction of discourses of quality assurance and of quality improvement in the education policies in the AQTP. The analysis then shows how the newspaper items construct a commonsense discourse on teacher quality that rejects these policy discourses as it presents an authoritative public voice on teacher quality. It shows how this commonsense discourse is reinforced by the contributions of senior members of government to the media debates on quality schooling. The chapter concludes with comments on the ideological nature of public discourses on education. It shows how 
such discourses work within the public sphere to define educational policies and identities in particular ways.

\section{Media and Education Policy as Public Discourses}

Media texts and educational policies can be understood as discourses, that is, as social practices that represent social realities in particular ways, and construct particular social positions (Thomas, 2006). Such an understanding recognises the importance of language and text in contemporary society, for as Luke (2002) argues, "text, language and discourse have become the principal modes of social relations, civic and political life, economic behaviour and activity, where means of production and modes of information become intertwined in analytically complex ways” (p. 98). Understanding media and policy as discourse draws on the Foucauldian theory of discourse as the conjunction of power and knowledge (cf. Foucault, 1976). Discourses are manifestations of power (Harvey, 1996) in that they are sites of struggle over understandings of reality. Discursive struggles construct a preferred discourse that presents an hegemonic, common-sense version of the world (Allan, 1998; A. Luke, 1995/1996), an "authorial voice” that suppresses differences and masks the socially constructed nature of the discourse (Gardiner, 1992, p. 192).

Media and policy discourses work within discursive struggle to define not only what can be said and thought about education, but also to define who can speak, where, when and with what authority. Media texts are forms of public, institutional discourse embedded in relations of power and resistance (cf. Bell \& Garrett, 1998; Fairclough, 1995; Falk, 1994; Higgins, 1991; van Dijk, 1988a, 1988b). As Allan (1998) notes, news discourse works to inscribe a preferred map of social reality in which certain definitions of reality are aligned with common sense, thus naturalizing a preferred range of truth claims. Similarly, educational policy can be understood as discursive practices and educational policies can be examined as discourserelated problems (cf.Bacchi, 2000; Ball, 1993; Gale, 2003; Taylor, 2004; Thomas, 2005). 
Policy documents are discursively produced 'within particular contexts whose parameters and particulars have been temporarily (and strategically) settled by discourse(s) in dominance” (Gale, 1999, p. 405). The policy process, therefore, is a matter of discursive and textual practices (Jones, Lee, \& Poynton, 1998, p. 146). It is a site of discursive struggle between competing but unequal interests (Ball, 1993; Gale, 2003; Taylor, Rizvi, Lingard, \& Henry, 1997).

Both media and policy discourses may be described as public discourses that work to influence public opinion. In this chapter, the term "public" does not refer to the state (government) or to private commodity-and service-producing organizations. Rather, the public is concerned with communal well-being and community interests (Sholar, 1994). That is, publicness is the principle that corresponds to the public sphere, to that sphere in which public opinion is formed (Habermas, 1996). It constitutes the "social spaces and social practices in which people as citizens dialogue on issues” (Chouliaraki \& Fairclough, 1999, p. 137). However, the Habermasian (1989/1962; 1996) public sphere has been critiqued for its universalistic nature and its failure to address the plurality and fragmentation of contemporary social life (Benhabib, 1996; Calhoun, 1992; Fraser, 1992; Hunter, 2001). The possibilities for critical, rational deliberation in contemporary media-saturated society have been questioned also (Gerstl-Pepin, 2007; Lunt \& Stenner, 2005). Further, as Rundle (2007) notes, the structural and psychological changes created by the new media, global markets, and image cultures have utterly reconstructed the public sphere in which national political conversations were hitherto based and that, barring a huge global developmental reversal, it is not returning (p.28).

These changes, together with the criticisms noted above, have led to work that has reconceptualised the public sphere as discursive space, that is, as a complex arena of discursive relations (McLaughlin, 1994; Thomas, 2004). Such an understanding of the public 
sphere recognises the fluid, dynamic structure of the public sphere and enables an analysis of the discursive connections made across local sites. The following analysis is informed by this understanding as it traces media and policy discourses that were constructed in public debates on education.

The public sphere is a media saturated one, producing and disseminating descriptions of the social order and social identities (Barker, 1999; Gerstl-Pepin, 2007). Media discourses, while produced within privately owned organisations (Cunningham \& Turner, 2002) are intended to influence the public sphere and thus shape social relations (Falk, 1994; Marginson, 1993). Indeed, media discourses are the means by which government policy is interpreted for, as Falk (1994) has shown, "the newspaper medium selects, develops and presents for public consumption what the discursive themes of policy will be” (p. 11). That is, media collude with government to construct particular versions of what public policy should be (Anderson, 2007; C. Luke, 2007), acting as conduits for policy agendas (Collins, Abelson, Pyman, \& Lavis, 2006). Policy documents can be described as the public expression of the intent of government (Marginson, 1993) and as the constitution of the official discourse of the state (Codd, 1988). However, as the state has responded to the demands of increasingly more assertive interest groups, they have become the bureaucratic instruments that administer public expectations (Taylor et al., 1997), and as such, constitute discourses directed to the public sphere. Thus, despite being produced in either the private or the government sectors, both policy and media discourses can be conceptualised as discourses of the public sphere, that is, as sites where power is exercised by contesting groups in discursive struggles over the construction of a public authoritative voice, in this case, on education.

Critical Discourse Analysis (CDA) has been shown to be a valuable tool for investigating both media and educational policy discourses, and for investigating the links between these public discourses (cf. Thomas, 2004, 2006). CDA is a transdisciplinary method of analysis 
that draws on an ensemble of social science techniques. As such it provides a flexible means to analyse the discursive interrelationships inherent in complex social processes, including the interrelationships between media and policy discourses. It is employed in the following analysis to trace the discourses on quality and standards constructed both in education policy and in The Australian. Of principal concern is the discursive construction of an authorial, public voice on teachers.

\section{The Australian Government Quality Teacher Programme}

The Australian Commonwealth Government established the Australian Government Quality Teacher Program (AGQTP) in 1999. The programme was outlined in two reports: Teachers for the $21^{\text {st }}$ Century (Department of Employment Education Training and Youth Affairs, 2000) and Australia's Teachers: Australia’s Future (Department of Education Science and Training, 2003). Together these reports mapped out a national project that had two objectives: “ to update and improve teachers' skills and understanding in priority areas” and "to enhance the status of teaching in government and non-government schools” ( Australian Government Department of Education, Science and Training, 2005, p. 1). The evaluation of the programme recommended that the AGQTP be continued for another four years, that is until 2009 and focus on the one objective, "to increase teacher and school leader skills and understanding” ( Australian Government Department of Education, Science and Training, 2005, p. ix). Thus, the policy discourses constructed in these two reports continued to guide Australian Government policy in 2006, the period in which The Australian published a number of items on teacher quality.

These two policies constructed two discourses on quality and standards, both of which emphasised the importance of professional standards. However, each discourse advocated the development of standards through different means and for different purposes. Teachers for 
the $21^{\text {st }}$ Century constructed a discourse that emphasised the link between national productivity and quality schooling, and in particular, teacher quality. It noted that education of the highest quality is the foundation of all our futures. It is education which empowers us to rise to the challenges of social, cultural, economic and technological change that we confront today ... education of the highest quality requires teachers of the highest quality. (Department of Employment Education Training and Youth Affairs, 2000, p. 3)

The policy outlined a program designed to improve teacher quality and to increase the effectiveness of schools. The following table contains the description of the program. Table 1: Repetition in Teachers for the $21^{\text {st }}$ Century

Teachers for the $21^{\text {st }}$ Century will improve teacher quality and increase the number of highly effective Australian schools in order to maximise student learning outcomes. It will do so by:

- lifting the quality of teaching through targeted professional development and enhancing professional standards;

- developing the skills of school leaders;

- $\quad$ supporting quality school management; and

- recognising and rewarding quality schools, school leaders and teachers.

(Department of Employment Education Training and Youth Affairs, 2000, pp. 3, 5, 13).

This description was repeated word for word three times throughout the policy: in the introduction by the then Federal Minister for Education, in the Executive Summary, and in the body of the report when outlining the central purpose of the program, to construct a deficit discourse of teachers and schools. 
The discursive importance of repetition stems from the repetitive use of words to constitute "a particular way of dividing up some aspect of reality which is built upon a particular ideological representation of that reality” (Fairclough, 2001, p. 96) that works to privilege certain meanings over others as common sense and uncontestable. The use of repetition in Teachers for the 21st Century constructed a deficit discourse of teachers and schools. This discourse painted a picture of low educational standards in Australian schools and repeatedly stressed the need to raise these standards (Department of Employment Education Training and Youth Affairs, 2000, p. 12). The quality of the teaching profession was identified as being both the cause of these low standards and as the means by which educational standards will be raised. Teachers were required to work together within their school communities to identify goals, define standards and expectations, review and refine teaching practices and prioritise areas for action and improvement. They [were to] accept responsibility for assessing the impact of their teaching on student outcomes and report on and [were to be] accountable for these outcomes. (Department of Employment Education Training and Youth Affairs 2000, p. 11)

In this way, standards were explicitly linked to student outcomes and to teacher accountability. Teachers were "the primary means by which educational standards will be raised” (p. 12). However, teachers were depicted as needing external assistance to set professional standards. Indeed, standards were to be developed "by working with and through the teaching profession” (p. 12) in "a cooperative effort from the Commonwealth Government, State and Territory government and non-government education providers, schools, principals, professional associations and parents” (p. 12). That is, the teaching profession was not granted autonomy to develop standards and determine the norms of 
professional practice that would lead to improved student outcomes, but rather were to be guided by government.

Teachers for the $21^{\text {st }}$ Century constructed a preferred discourse of quality assurance (Sachs, 2003), one that emphasised regulation and certification through standards. Standards "were the means of improving the quality of teaching and enhancing the professional standing of teachers” (Department of Employment Education Training and Youth Affairs, 2000, p. 17). That is, it was a regulatory discourse of quality in which teachers were positioned as needing to improve their skills. The focus of such a discourse was on the attainment of standards that would lead to improved performance.

Rather than focusing on a lack of skills and the need for regulation through the introduction of national standards, the second policy document, Australia's Teachers: Australia's Future, constructed a discourse on quality teachers and schools that focused on innovation. Quality schooling was seen to be necessary to sustain innovation, and was defined in terms of the renewal of cultures of continuous innovation. Unlike Teachers for the $21^{\text {st }}$ Century, quality was not seen to be problematic, although complacency about standards was to be avoided.

Australia has a comprehensive and inclusive education system which performs very well in international comparisons, meeting standards for a well-educated citizenry and workforce. Average standards are high and the best students and schools are amongst the best anywhere, but there is no cause for complacency. (Department of Education Science and Training, 2003, p. xvii)

The report therefore, emphasised not the raising of standards, but the "energising [of] schools for innovation” (Department of Education Science and Training, 2003, p. 217). Teachers were positioned by this discourse as “the key to mobilising schools for innovation” 
(Department of Education Science and Training, 2003, p. xvii) as the discourse emphasised the role of standards in teacher development through professional learning.

The preferred discourse constructed in Australia's Teachers Australia's Future was a discourse of quality improvement through standards (Sachs, 2003). Such a discourse promotes a developmental approach to standards in the context of teacher professional development, learning and career advancement. It identifies the development of standards as a means of making explicit the norms of professional practice to which pupils are entitled and of which the wider public has a legitimate right to be assured. This discourse advocates transparency regarding the social and professional expectations and obligations of teachers. Professional standards developed in this context signal a democratic form of professionalism (Ingvarson, 1998) and are most likely to be in the best interests of the profession (Sachs, 2003).

Thus, the discourses on teacher quality constructed in the education policies that form the basis of the AGQTP both emphasise the introduction of professional standards. The preferred discourse constructed in the first policy was a discourse of quality assurance, focussing on the use of standards to improve performance. The preferred discourse in the second policy was a discourse of quality improvement that focused on the use of standards as a basis of reforming the profession. While the two discourses can be distinguished on the basis of varying degrees of professional autonomy over the control and ownership of the development and monitoring of the standards, both discourses are concerned with the processes of ensuring teacher quality. In contrast, as the following analysis demonstrates, the preferred media discourse constructed in The Australian in 2006 is a common sense discourse on quality that measures teacher quality in terms of a product, student outcomes.

The 2006 Campaign on Education in The Australian 
In 2006, The Australian, published a large number (141) items on education. These items raised concerns about the standard of education in Australian schools. They were part of a long-standing campaign on education that targeted

the alleged transgressions of progressive literacy teachers and educators. The newspaper’s explicit intention has been to change the literacy curriculum. The Coalition government has also played an active role in the campaign, aiming to assume greater centralised control of literacy education via a national curriculum. (Snyder, 2008, p.

The items published in 2006 covered five broad themes: the teaching of English/literacy, science/mathematics teaching, outcomes-based education (OBE), the history curriculum and the quality of teachers. Fifteen items focused specifically on the quality of teaching and will form the basis of the following analysis. Teacher quality was raised as a concern in many of the items that focused on the other themes also. For example, an article (Box, 2006, p. 8) that dealt with the teaching of literature was headed "Writer backs PM attack on teaching” and repeated the Prime Minister's comments on contemporary teaching practices in literature as “rubbish” and on outcomes-based education as "gobbledegook”.

Of the fifteen items on quality teaching, seven, or almost half, were published in the months of July and August when the number of articles on Education peaked. Items that covered the lead up to, the reporting on, and the aftermath of, a national summit on the History curriculum held in mid-August 2007 dominated the news coverage in these months. Significantly, three articles on the quality of teaching were published in the last three days of August following the summit. Two, headed "Teachers are not so clever any more” (Ferrari, 2006a, p. 1) and “A failure to make the grade” (Leigh \& Ryan, 2006, p. 8), raised questions about the quality of teachers, and so led the reader to question teachers' abilities to make decisions about appropriate History curricula. 
Declarative sentences are a characteristic feature of most media texts, including newspaper items. Making statements involves the exchange of knowledge or what Fairclough (2003) calls epistemic modality. Epistemic modality refers to the authors' commitment to the truth. Assertions or statements of fact realise strong commitments to truth. Evaluation refers to the ways in which authors commit themselves to values and concerns the authors' commitment to desirability (Fairclough, 2003). Of particular interest to the following analysis are evaluative statements about desirability and undesirability, about what is good and what is bad. Thus, analyses of modality and evaluation involve analyses of how the world is represented, of the desirability or undesirability of these representations, and of how an authoritative voice on such realities is constructed.

This was certainly the case in the 15 items under analysis. However, several of these items also included questions. A total of eight questions were raised in the 15 items on teacher quality. The eight questions, listed in chronological order, were:

1. The question at the forefront of every parent's mind must therefore be: how trustworthy are those hands? (Auty, 2006, p. 14)

2. Did someone mention that dreaded T-word - testing? (Auty, 2006, p. 14)

3. What can be done to make teaching more family friendly? (Donnelly, 2006c, p. 24)

4. Why not free schools to reward better-performing teachers, especially women, instead of having a centralised, lock-step salary scale? (Donnelly, 2006c, p. 24)

5. So what is the best way to reward better performing teachers? (Donnelly, 2006b, p, 14)

6. Should we worry if the literacy and numeracy of new teachers has fallen? (Leigh \& Ryan, 2006, p. 8)

7. Why have schools been powerless to sack bad teachers, child abusers and thieves? (Wheeldon, 2006, p. 29) 
8. What other issues might be on the agenda? (Donnelly, 2006a, p. 17)

These questions were found in the feature articles, guest columns written by political, social, religious or academic leaders (Harriss, Leiter, \& Johnson, 1992, p. 468), which did not report an event but, rather, commented on a particular issue. The nature of such columns privileged the writer as an authority on the issue under discussion. The use of questions in the feature articles is significant as asking questions indicates a knowledge exchange where the (authoritative) author elicits the reader's commitment to truth (Fairclough, 2003). An analysis of the questions raised in the features on teacher quality, therefore, highlights those features evaluated as desirable or undesirable by authoritative voices on education, features to which the reader's commitment is sought. The eight questions listed above highlight features that raise concerns about the trustworthiness of teachers, including their ability to make decisions about assessment and curriculum; the falling standard, or quality, of teachers, including the notion of better-performing teachers, and by presupposition bad teachers; and an agenda on education that should be taken to address teacher quality. That is, these features work together to construct a preferred media discourse on schools and teachers.

The trustworthiness of teachers

The first item that explicitly looked at the quality of teachers was a feature item published in February (Auty, 2006). This item was the first to question the trustworthiness of teachers.

Whether we like it or not the future character of Australia lies fairly and squarely in the hands of our educators. The question at the forefront of every parent's mind must therefore be: how trustworthy are those hands? (Auty, 2006, p. 14)

As the following quote shows, the item depicted teachers in an unfavourable light, as “educational brainwashers" and as "habitual liars", and questioned their teaching of the curriculum, especially the history curriculum. 
My belief is that, like habitual liars, deliberate educational brainwashers are quick to see their own habits mirrored in the actions of others. According to such people and their international mentors no one ever acted dispassionately even when making every effort to do so... Indeed this precise argument is used regularly nowadays as a justification for the deliberation fabrication of history. (Auty, 2006, p. 14)

These constructions were to be repeated throughout the year. For example, Wheeldon (2006) explicitly raised the question of the loss of trust in teachers and its leading to the undervaluation of teachers in an item published in December.

An anonymous item, anonymous in that there was no byline, published in March described teachers as “Know nothings” who "make a mockery of education” (MATP, 2006, p, 13). That item went on to establish an opposition between "hard-Left cadre of theoreticians and educrats who believe that the worst things kids can be exposed to are competition, memorisation and John Howard” (MATP, 2006, p. 13) and individual teachers doing “excellent, even heroic, jobs in the classrooms” (MATP, 2006, p. 13). Binary oppositions construct a relationship between a preferred version of reality on the one hand and the description of a behaviour or event on the other. The relationship is constructed in such a way that the event or behaviour does not fit the rules or categories of preferred version of reality. The effect is to construct "a binary opposition of the permitted and the forbidden” (Foucault, 1977, p. 183). The use of binary oppositions enables the Other to be identified as the source of problems (Apple, 1989; van Leeuwen, 1996). Thus, in the opposition noted above, "good, heroic” teachers were valued positively over "Left cadre theoreticians and educrats” who fight parents and governments as they refuse to adopt a uniform A-E report card system. As Auty (2006, p. 14) asked, “did someone mention that dreaded T-word - testing?” (p. 14). Auty also used an opposition to identify undesirable and desirable teaching practices. Reflecting the opposition between the heroic teacher and the Left educrat, this opposition 
contrasted radicalism with "anything established or traditional or - worst of all conservative" (Auty, 2006, p. 14). Radicalism is found in "the methods and emphases employed by newer generations of teachers” (Auty, 2006, p. 14). Radicalism was seen to be undesirable for it politicises the classroom and

the basis for such a belief [in radicalism] rests almost always on rhetorical cliché rather than empirical evidence does nothing to lesson its self-righteous force. The phenomena I describe as the rhetoric of radicalism is ubiquitious in education and the arts where it creates untold damage through causing a too-ready abandonment of tested principles. (Auty, 2006, p. 14).

These items depicted undesirable teachers as radical, left-leaning "educrats" who fight with parents and governments, who avoid testing, who fabricate history, and most importantly are not to be trusted. They were the Other, the source of problems in education. The falling standards of teachers Not only are untrustworthy teachers constructed as the source of problems in education, but teacher standards were depicted as falling. One item (Ferrari, 2006a) states that "teachers are not as smart as they were 20 years ago, an Australian-first study concludes in a finding that will reinforce concerns over declining classroom standards” (p. 1). The study conducted by two economists compared the literacy and numeracy standards of new teachers over a 20 year period and found that "the standards of new teachers has fallen substantially” (Leigh \& Ryan, 2006, p. 8), particularly the standards of women teachers. This latter finding echoed the theme of an earlier item that sent "an urgent call to schoolmarms” (Donnelly, 2006c, p. 24) and outlined the desirability of the recruitment and retaining of high-achieving women as teachers.

Other items presented an alternative view on the standards of teachers. For example, an item, published on the day after the two items noting the declining standards of new teachers, 
claimed that "Uni’s top students choose teaching” (Ferrari, 2006b, p. 7) because "more than half the students starting a teaching degree at one of the nation's leading universities chose a teaching career, despite having the marks to study engineering, arts, science or medicine” (Ferrari, 2006b, p. 7). New teacher education students at this university were high-achievers. Another item reported on a conference of educators that "defended the 'impressive record' of Australia’s school teachers” (Illing, 2006, p. 2). However, these views on the standards of teachers and teaching were given little credence in the feature articles that focused on the quality of teachers, although recognition was given to "better performing teachers" (Donnelly, 2006b, 2006c) in discussions of what should be done to address the problem of quality in Australian schools.

\section{Looking ahead to what should be done}

The solution to improving teacher quality was seen to lie in freeing schools "to reward betterperforming teachers, especially women, instead of having a centralised, lock-step salary scale” (Donnelly, 2006c, p. 24). Wheeldon (2006) encapsulated this solution best when she stated that

loss of trust in a handful of teachers leads to undervaluation of them all. This undervaluation becomes a short-sighted excuse for a depression of salaries, which of course lowers the quality of intake of new teachers, and so the spiral goes on. Now we do not have enough teachers to teach our children, largely because of our inability to terminate those who have lost our confidence. Sack the bad ones, pay the good ones professional salaries. Give teachers respect. Then stand back and watch intelligent people, including men, line up for a very rewarding career. (p. 29)

Such a solution constructed an opposition between teachers, that of better-performing, good teachers and bad teachers, who were likened to child abusers and thieves (Wheeldon, 2006, p. 29). Better-performing teachers were identified as teachers who "are more 
successful in improving students” results, especially in hard-to-staff schools in disadvantaged areas” (Donnelly, 2006b, p. 14). That is, judgements about good teachers are linked to students’ results and accountability (Donnelly, 2006a). Good teachers should be rewarded, bad or underperforming teachers on the other hand, should be dealt with, fired (Donnelly, 2006a), sacked (Hannan, 2006; Wheeldon, 2006).

In the final feature article on education, published in the final edition of The Australian for the year, Donnelly outlined an agenda for school education the "burning issue that will only get hotter in 2007” (Donnelly, 2006a, p. 17). In that item, Donnelly reiterated the issues identified above, issues that together worked to construct a preferred discourse on schools and teachers. The discourse identified "the widespread concerns about falling standards and academic rigour in the curriculum” (Donnelly, 2006a, p. 17). Teachers, described as untrustworthy, radical, "know nothings” with lower standards in literacy and numeracy, were depicted as a key factor in these concerns. Consequently, increased accountability was needed in order to reward better-performing, good teachers and deal with bad teachers. Judgements on teacher performance should be made on the basis of students' results.

Such a discourse was a discourse on standards as commonsense (Sachs, 2003). It constructed a view of teacher standards and quality that saw a regulatory, framework that controlled teachers and teaching as commonsense, "sack the bad ones, pay the good ones professional salaries” (Wheeldon, 2006, p. 29). It presented an uncritical view of standards as benchmarks to be imposed on the profession, benchmarks measured against students' results in literacy and numeracy.

Government contributions to the public debate on teaching and teachers

It was noted earlier in this paper that the news coverage of the issue of teacher quality peaked in the months of July and August, that is in the time of the national summit on the History curriculum held in mid-August 2007. Three items directly attributed to senior 
members of the Australian government, specifically the Prime Minister of Australia, John Howard, and the Minister for Education, Julie Bishop, were included in this coverage. These items differed from the previously noted item that reported on statements by the then Prime Minister, John Howard, statements that described current teaching practices as "rubbish" and “gobbledegook”. Rather than reporting on statements made by the Prime Minister and the Education Minister, the items contained extracts of speeches given by these senior members of the government. As the following analysis will show, the speeches of both the Minister and the Prime Minister constructed a discourse of poor teaching that endorsed the commonsense discourse traced in The Australian.

This government discourse was characterised by declarative sentences that asserted strong commitments to the truth about history teaching. The discourse constructed the teaching of history as being problematic. Specifically, there were

two glaring problems with regard to the teaching of Australian history: the quantitative problem and the qualitative problem. Not enough students are learning Australian history; and there is too much political bias and not enough pivotal facts and dates being taught” (Bishop, 2006c, p. 12).

The solution to this problem was a renaissance in the teaching of history that focused on big themes, such as the Enlightenment and the British inheritance, and that developed "a body of knowledge that is rich in dates, facts and events” (Bishop, 2006c, p. 12). The truth of this construction was established by the repeated use of the adjective proper as in “I don't think you can have a proper teaching and comprehension of Australian history” (Howard, 2006, p. 15) and the modal adverb obviously as in "we obviously have to see Australia as heavily influenced by the Western intellectual position, the Enlightenment and all that's associated with it” (Howard, 2006, p. 15). The evaluation of history teaching in the discourse constructed by senior member of the Australian government worked to establish current 
practices in the teaching of history as being undesirable. While this discourse specifically refers to History teaching, the questioning of the current teaching practices presupposes a questioning of teacher quality. Indeed, this is apparent in the full speech given by the Minister for Education, where reference is made to "unqualified or scarcely-qualified teachers" (Bishop, 2006a).

Further, as noted earlier, statements of desirability and undesirability position the speakers, in this case, the Minister for Education and the Prime Minister, as the authoritative voices on the teaching of History. Such a positioning is evidenced also in the Minister and Prime Minister's use of the deictic categories I, we and our throughout their speeches. For example, the Minister for Education claims that

we have a rich and unique national story. We have to ask ourselves why so few of our children know it. Whatever the reasons, the situation is not good enough. I see this is an issue of national importance. I believe it’s time to fix it. (Bishop, 2006b, p. 11). The reason for the problem and the solution can be found in the Prime Minister's statement that "we want to bring about a renaissance of both interest in and understanding of Australian history, and that this must involve a greater focus on disciplined teaching and understanding of history in Australian schools” (Howard, 2006, p. 15).

In both these extracts, the use of deictic categories encourages the hearer/reader to identify with the interests outlined in the truth claims constructed in the discourse (Allan, 1998). That is, it positions the hearer/reader of the speech to agree with the construction of History teaching and teachers as problematic. At the same time, others who do not agree with these evaluations, specifically teachers, are positioned outside the discourse. Thus, the speeches of the two senior members of the Australian government construct a commonsense discourse of teaching and teacher quality. This discourse positions the Minister and the Prime Minister as the authoritative public voice on, and excludes teachers from, the debate (see the chapter by 
Bridges \& Bartlett in this volume for another example of the ‘truth' of institutional

discourse). Further, this discourse focuses on poor student outcomes, that is, on students' lack of knowledge of the facts of Australian history. As such, it such echoes and reinforces the commonsense discourse on teacher quality constructed in The Australian newspaper items analysed above.

\section{Constructing a shared authoritative public voice on education}

The above analysis has shown how The Australian and senior members of the then Federal Government conducted a campaign on teacher quality. The campaign was characterised by the use of right wing columnists writing in the opinion pages, attacks on the credibility of teachers and the intervention of senior members of the Government. The campaign resulted in the construction of a commonsense discourse on teaching and teachers in Australian schools. This discourse worked to naturalise, or reify, commonsense understandings of teachers in schools, privileging a decisive definition of low teacher quality that results in poor student outcomes. This privileged version of teacher quality is at odds with that constructed in the policy documents, which emphasised the development of professional standards. Indeed, the notion of a professional body that will "identify standards that are associated with best practice and certify how well teachers meet the criteria” (Donnelly, 2006b, p. 14) was seen to be flawed as such standards can be politicised or be "so vacuous as to appear useless” (Donnelly, 2006b, p. 14). This was seen to be "highly likely given that the board of Teaching Australia [the body established by the Australian Government 'as the national body for the teaching profession, to be conducted by teachers and school leaders' (Teaching Australia, 2006)] consists of the usual education suspects” (Donnelly, 2006b, p. 14). At the time, such attacks on the credibility of persons who were perceived to be at odds with Government policy was a "standard operating procedure for the Howard [the then Federal] Government” (Buchanan, 2008, p. 37). 
Thus, policy discourses on teacher quality, discourses that emphasised professional standards, and identified teachers as stakeholders in the introduction of these standards, were rejected in favour of a commonsense discourse on teacher quality. Such a discourse was characterised by statements that evaluated teachers as untrustworthy; as teaching inappropriate curriculum; as of a lower quality that teachers of previous generations; and who were responsible for falling standards and poor student outcomes in Australian schools. The discourse called for increased accountability for teachers, who were to be judged in terms of student outcomes and sacked if they were found wanting. Rather than focusing on the process of ensuring quality through professional standards, the focus was on a measurable product, thus simplifying, and so reducing the complexity of, the issue of quality teaching. In this way, the commonsense discourse on quality established an authoritative public voice on education and teacher quality.

The critical discourse analysis outlined in this chapter illustrated how discourses work to naturalise, or reify, commonsense understandings of issues in public debates on education. In so doing, it demonstrated the ideological nature of public discourses in debates about teachers and education. That is, it showed how discourses construct a hegemonic equilibrium that constituted particular realities through discursive practices in a complex process of contestation and negotiation, and in the making of discursive links across the sites of media, government and education policy. The analysis illustrated the complexity of the interrelationships between media and policy discourses. Rather than a bridge between contexts of policy-making (Ball, 1990; Wallace, 1994) or an unseen hand guiding the policymaking process (Wallace, 1993), it showed that the media is best described as an integral part of the proliferation of discourses that constitute public debates on education policies. That is, it demonstrated how the media acted as a conduit, colluding with government to generate debate on public policy in such a way that it constructed an authoritative public version of 
teacher quality. Finally, the analysis established that media discourses are essential to the construction of discursive threads within the complex web of contested meanings that characterise policy-making processes, working within the public sphere to construct an authoritative public voice that defines educational policies and identities in particular ways. 
Allan, S. (1998). News from Nowhere: Televisual News Discourse and the Construction of Hegemony. In A. Bell \& P. Garrett (Eds.), Approaches to Media Discourse (pp. 105141). Oxford: Blackwell Publishers.

Anderson, G. L. (2007). Media's Impact on Educational Policies and Practices: Political Spectacle and Social Control. Peabody Journal of Education, 82(1), 103-120.

Apple, M. W. (1989). Critical Introduction: Ideology and the State in Education Policy. In R. Dale (Ed.), The State and Education Policy (pp. 1-20). Milton Keynes: Open University Press.

Australian Government Department of Education, Science and Training. (2005). An Evaluation of the Australian Government Quality Teacher Programme 1999 to 2004, Canberra: Commonwealth of Australia.

Auty, G. (2006, Friday 3 February 2006). Teaching is failing the test. The Australian, p. 14.

Bacchi, C. (2000). Policy as Discourse: what does it mean? where does it get us? Discourse: studies in the cultural politics of education, 21(1), 45-57.

Ball, S. J. (1990). Politics and Policy Making in Education: explorations in policy sociology. London: Routledge.

Ball, S. J. (1993). What is Policy? Texts, Trajectories and Toolboxes. Discourse: The Australian Journal of Educational Studies, 13(2), 10-17.

Barker, C. (1999). Television, Globalization and Cultural Identities. Buckingham: Open University Press.

Bell, A., \& Garrett, P. (Eds.). (1998). Approaches to Media Discourse. Oxford: Blackwell Publishers.

Benhabib, S. (1996). Toward a Deliberative Model of Democratic Legitimacy. In S. Benhabib (Ed.), Democracy and Difference: Contesting the Boundaries of the Political (pp. 6794). Princeton, N.J.: Princeton University Press.

Bishop, J. (2006a). Forgetting Our Past, Failing Our Future: The Teaching of Australian History [Electronic Version]. Retrieved 26 May 2008 from http://www.dest.gov.au/Ministers/Media/Bishop/2006/08/b001170806.asp.

Bishop, J. (2006b, Thursday 17 August 2006). If we forget our nation's past, we will fail our future. The Australian, p. 11.

Bishop, J. (2006c, Thursday, 6 July 2006). Our classrooms need to make a date with the facts. The Australian, p. 12.

Box, D. (2006, Saturday, 22 April 2006). Writer backs PM on teaching. The Australian, p. 8.

Buchanan, J. (2008). Values, Research and Industrial Relations Policy: Recent Controversies and Implications for the Future. Dialogue (Academy of the Social Sciences in Australia), 27(1), 30-39.

Calhoun, C. (Ed.). (1992). Habermas and the Public Sphere. Cambridge, Massachusetts: The MIT Press.

Chouliaraki, L., \& Fairclough, N. (1999). Discourse in Late Modernity Rethinking Critical Discourse Analysis. Edinburgh: Edinburgh University Press.

Codd, J. (1988). The construction and deconstruction of educational policy documents. Journal of Education Policy, 3(3), 235-247.

Collins, P. A., Abelson, J., Pyman, H., \& Lavis, J. N. (2006). Are we expecting too much from print media? An analysis of newspaper coverage of the 2002 Canadian healthcare reform debate. Social Science \& Medicine, 63, 89-102.

Cunningham, S., \& Turner, G. (2002). The media and communications in Australia (2nd ed.). St. Leonards, N.S.W.: Allen \& Unwin. 
Department of Education Science and Training. (2003). Australia's Teachers: Australia's Future Advancing Innovation, Science, Technology and Mathematics. Retrieved 19 September, 2004, from http://dest.gov.au/schools/teachingreview/documents/MainReport.pdf

Department of Employment Education Training and Youth Affairs. (2000). Teachers for the 21st Century: Making the Difference. Canberra: Commonwealth of Australia.

Donnelly, K. (2006a, Saturday 30 December 2006). Gloves off for rumble in the blackboard jungle. The Australian, p. 17.

Donnelly, K. (2006b, Friday 14 July 2006). Right criteria for rewards. The Australian, p. 14.

Donnelly, K. (2006c, Saturday 6 May 2006). Sounding an urgent call to schoolmarms. The Australian, p. 24.

Fairclough, N. (1995). Critical discourse analysis: the critical study of language. London and New York: Longman.

Fairclough, N. (2001). Language and Power second edition (second ed.). Harlow, England: Longman.

Fairclough, N. (2003). Analysing Discourse and Text: Textual Analysis for Social Research. London: Routledge.

Falk, I. (1994). The Making of Policy: Media Discourse Conversations. Discourse: studies in the cultural politics of education, 15(2), 1-12.

Ferrari, J. (2006a, Monday 28 August 2006). Teachers are not so clever any more. The Australian, p. 1.

Ferrari, J. (2006b, Tuesday 29 August 2006). Uni's top students chooose teaching. The Australian, p. 7.

Foucault, M. (1976). Politics and the study of discourse. Ideology and Consciousness, 3, 726.

Foucault, M. (1977). Discipline and Punish (A. Sheridan, Trans.). London: Penguin Books.

Fraser, N. (1992). Rethinking the Public Sphere: A Contribution to the Critique of Actually Existing Democracy. In C. Calhoun (Ed.), Habermas and the Public Sphere (pp. 109142). Cambridge, Massachusetts: The MIT Press.

Freesmith, D. (2006). The Politics of the English Curriculum: Ideology in the Campaign Against Critical Literacy in The Australian. English in Australia, 41(1), 25-30.

Gale, T. (1999). Policy Trajectories: treading the discursive path of policy analysis. Discourse: studies in the cultural politics of education, 20(3), 393-407.

Gale, T. (2003). Realising Policy: the who and how of policy production. Discourse: studies in the cultural politics of education, 24(1), 51-65.

Gardiner, M. (1992). The dialogics of critique M. M. Bakhtin and the theory of ideology. London: Routledge.

Gerstl-Pepin, C. (2007). Introduction to the Special Issue on the Media, Democracy, and the Politics of Education. Peabody Journal of Education, 82(1), 1-9.

Habermas, J. (1989/1962). The structural transformation of the public sphere: an inquiry into a category of bourgeoise society (T. w. Burger \& F. Lawrence, Trans.). Cambridge, Massachusetts: MIT Press.

Habermas, J. (1996). The Public Sphere. In P. Marris \& S. Thornham (Eds.), Media Studies: A Reader (pp. 55-59). Edinburgh: Edinburgh University Press.

Hannan, E. (2006, Friday 3 March 2006). Update or face sack, teachers told. The Australian, p. 7.

Harriss, J., Leiter, K., \& Johnson, S. (1992). The Complete Reporter Fundamentals of News Gathering, Writing, Editing (Sixth ed.). New York: Macmillan.

Harvey, D. (1996). Justice, Nature \& the Geography of Difference. Oxford: Blackwell Publishers. 
Higgins, C. (1991). Broadcast news: a linguistic mode of analysis. Continuum: The Australian Journal of Media and Culture, 5(1), 149-165.

Hobbs, M. (2007). 'More paper than physical': The reincorporatoion of News Corp and its representation in the Australian press. Journal of Sociology, 43(3), 263-281.

Howard, J. (2006, Friday 18 August 2006). Let's understand our Western institutional heritage. The Australian, p. 15.

Hunter, N. D. (2001). Accommodating the Public Sphere: Beyond the Market Model. Minnesota Law Review, 85(6), 1591-1637.

Illing, D. (2006, Monday 18 December 2006). Teachers defend their 'impressive record'. The Australian, p. 2.

Ingvarson, L. (1998). Teaching standards: foundations for professional development reform. In A. Hargreaves, A. Lieberman, M. Fullan \& D. Hopkins (Eds.), International Handbook of Educational Change. Amsterdam: Kluwer.

Jones, G., Lee, A., \& Poynton, C. (1998). Discourse analysis and policy activism: readings and rewritings of Australian university research policy. In A. Yeatman (Ed.), activism and the policy process (pp. 146-170). St Leonards, NSW: Allen \& Unwin.

Leigh, A., \& Ryan, C. (2006, Monday 28 August 2006). A failure to make the grade. The Australian, p. 8.

Luke, A. (1995/1996). Text and Discourse: An Introduction to Critical Discourse Analysis. In M. W. Apple (Ed.), Review of Research in Education 21 1995-1996 (pp. 3-48). Washington, DC: American Educational Research Association.

Luke, A. (2002). Beyond Science and Ideology Critique: Developments in Critical Discourse Analysis. Annual Review of Applied Linguistics, 22, 96-110.

Luke, C. (2007). As Seen on TV or Was that My Phone? New Media Literacy. Policy Futures in Education, 5(1), 50-58.

Lunt, P., \& Stenner, P. (2005). The Jerry Springer Show as an emotional public sphere. Media, Culture \& Society, 27(1), 59-81.

Marginson, S. (1993). Education and public policy in Australia. Sydney: Cambridge University Press.

MATP. (2006, Wednesday 1 March 2006). KNOW NOTHINGS - NSW teachers make a mockery of education. The Australian, p. 13.

McLaughlin, L. (1994). Introduction: Critical Media Pedagogy and the Public Sphere. Journal of Communication Inquiry, 18(2), 5-7.

McLeod, J., \& Yates, L. (2006). Making Modern Lives Subjectivity, Schooling, and Social Change. Albany: State University of New York Press.

Rundle, G. (2007). Power Intellectuals in the Howard era. arena magazine, 91, 25-31.

Sachs, J. (2003). The Activist Teaching Profession. Buckingham: Open University Press.

Sholar, S. E. (1994). Habermas, Marx and Gramsci: Investigating the Public Sphere In Organisational Communication And Public Relations Courses. Journal of Communication Inquiry, 18(2), 77-92.

Snyder, I. (2008). The Literacy Wars Why teaching children to read and write is a battleground in Australia. Crow's Nest, NSW: Allen \& Unwin.

Taylor, S. (2004). Researching educational policy and change in 'new times': using critical discourse analysis. Journal of Education Policy, 19(4), 433-451.

Taylor, S., Rizvi, F., Lingard, B., \& Henry, M. (1997). Educational Policy and the Politics of Change. London: Routledge.

Teaching Australia. (2006). Strategic Plan 2006-2009. Retrieved 18 December 2008 from http://www.teachingaustralia.edu.au/ta/webdav/site/tasite/shared/Publications\%20and \%20Covers/Our\%20Plan:\%202006-2009.pdf 
Thomas, S. (2004). Reconfiguring the Public Sphere: implications for analyses of educational policy. British Journal of Educational Studies, 52(3), 228-248.

Thomas, S. (2005). The construction of teacher identities in educational policy documents: a Critical Discourse Analysis. Melbourne Studies in Education, 46(1), 25-44.

Thomas, S. (2006). Education Policy in the Media: Public Discourses on Education. Teneriffe: Post Pressed.

van Dijk, T. A. (1988a). News Analysis. Hillsdale, New Jersey: Lawrence Erblaum Associates.

van Dijk, T. A. (1988b). News as Discourse. Hillsdale, New Jersey: Lawrence Erblaum Associates.

van Leeuwen, T. (1996). The representation of social actors. In C. R. Caldas-Coulthard \& M. Coulthard (Eds.), Texts and Practices Readings in Critical Discourse Analysis (pp. 32-70). London: Routledge.

Wallace, M. (1993). Discourse of derision: the role of the mass media within the education policy process. Journal of Education Policy, 8(4), 321-337.

Wallace, M. (1994, 4-8 April, 1994). The Contribution of the Mass Media to the Education Policy Process. Paper presented at the Annual Meeting of the American Educational Research Association, New Orleans.

Wheeldon, J. (2006, Saturday 2 December 2006). Blackboard bungle. The Australian, p. 29. 